\title{
Chemical composition of hulled, dehulled and naked oat grains
}

\author{
W. Biel", E. Jacyno \& M. Kawęcka \\ Department of Pig Breeding, Animal Nutrition and Food, West Pomeranian University of Technology in Szczecin, \\ 10 Judyma Street, 71-460 Szczecin, Poland
}

(Received 1 February 2014; Accepted 13 May 2014; First published online 11 July 2014)

\begin{abstract}
Copyright resides with the authors in terms of the Creative Commons Attribution 2.5 South African Licence.
See: http://creativecommons.org/licenses/by/2.5/za

Condition of use: The user may copy, distribute, transmit and adapt the work, but must recognise the authors and the South African Journal of Animal Science.
\end{abstract}

\begin{abstract}
The objective of the work was to evaluate the influence of genetic and mechanical removal of hulls from oat grains on their nutrient content. The studies included three cultivars and six lines of oat grains. In grain samples of hulled ( 5 samples), dehulled (5 samples) and naked (4 samples) oats, the following components were determined: chemical composition (ash, crude protein, crude fat, crude fibre and its components) and amino acids and fatty acid composition. The grain of naked and dehulled oats contained significantly more crude protein, crude fat and polyunsaturated fatty acids, and considerably less saturated fatty acids and crude fibre than hulled oats. In addition, the dietary fibre composition was more favourable than the naked oats. The coefficients of nutritional values of the protein (total essential amino acids, essential amino acid index and amino acids score) of naked oats were higher than hulled and dehulled oats. In all the tested oat grain samples, lysine was the most limiting amino acid. The study showed that genetic and mechanical reduction of the proportion of hulls in oat grains resulted in a significant decrease in dietary fibre content and a significant increase in nutrient content.
\end{abstract}

Keywords: Hulled and dehulled oat grains, naked oat grains, chemical composition

\# Corresponding author: wioletta.biel@zut.edu.pl

\section{Introduction}

Oat grains (Avena sativa) have multifunctional uses, including as animal feed, human food and in health care. However, the cultivation area of oats in the world is remarkably smaller than for other cereal crops such as maize, wheat and barley (Koehler \& Wieser, 2013). This is probably owing to the lower yield of oats compared with the other cereals (Brand et al., 2003). Oats tolerate wet weather and acidic soils far better than other cereals, are resistant to disease, and require less agro-chemical and fertilizer input (Givens et al., 2004). As a consequence, their production costs may be similar to wheat or barley.

The nutritional value of oat grain makes it a very useful component of the diet for humans and animals. The amino acid composition of oat grains is superior to that of other cereals because its major storage protein is globulin (Klose \& Arendt, 2012). Globulins have a higher concentration of lysine and other essential amino acids than prolamins, which are typical cereal storage proteins (Shewry \& Halford, 2002). Oat also contains a high percentage of lipids, particularly unsaturated fatty acid (Welch, 1995; Peterson, 1998; Zhou et al., 1998).

Increasing interest in oat utilization for human consumption has been stimulated by the need for soluble fibre, particularly $\beta$-glucans in diet, which have beneficial effects on health (Chen et al., 2006; Wood, 2007; Hsueh et al., 2011). For animal feed, however, low $\beta$-glucan concentration is desirable, particularly for poultry (Guenter, 1993).

The high-fibre content, which depresses the available energy of hulled oat grain, restricts its use as an animal feed, particularly for pigs and poultry (Morris, 1990). Genetic removal of the glumes from oat grain (naked oat) considerably improved its chemical composition and nutritional value (Brand et al., 2003). Naked oat grain has a lower fibre and higher energy value, and contains more protein and lipids compared with hulled oat grain (Brand et al., 2003; Givens et al., 2004; Biel et al., 2009). As an alternative to naked oat, hulls can be separated from groats by dehulling grain before being fed to animals.

The aim of this study was to evaluate the influence on the nutrient content of genetic and mechanical removal of hulls from oat grain. 


\section{Materials and Methods}

The research material comprised two cultivars (Krezus and Bingo) and three lines (STH 6106, STH 6108, STH 7105) of hulled and dehulled oat, and one cultivar (Polar) and three lines (STH 7202, STH 7205, STH 7206) of naked oat. Hulled and naked oat grain samples were derived from the plot trials carried out in

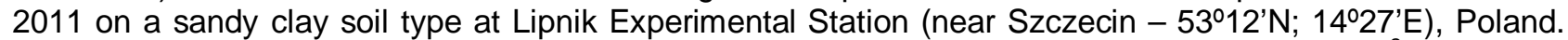
The experiment was carried out on a light soil of the IVb botanical class, using $550 \mathrm{grains} / \mathrm{m}^{2}$ and $90 \mathrm{~kg}$ $\mathrm{N} / \mathrm{ha}$. Hulled oat grains were dehulled with an impact laboratory oat dehuller (LH 5095, Codema, USA). The grain samples were stored in tightly closed glass jars at room temperature pending analysis.

The chemical compositions of all grain samples were determined from the following AOAC (2006) procedures. The dry matter was established by drying the samples in an oven at $105^{\circ} \mathrm{C}$ until a constant weight was obtained. Ash was ascertained by incineration in a muffle furnace at $580{ }^{\circ} \mathrm{C}$ for $8 \mathrm{~h}$. Crude protein $(\mathrm{N} \times 6.25)$ was obtained by the Kjeldahl method, using the Büchi Distillation Unit B-324 (Büchi Labortechnik AG, Switzerland). Ether extract was detected by Soxhlet extraction with diethyl ether. Crude fibre was determined with a fibre analyser, ANKOM 220 (ANKOM Technology, USA). Nitrogen-free extract was obtained by subtracting the sum of moisture, ash, crude protein, crude fat and crude fibre from 100 . The fibre components were ascertained using the detergent method according to Van Soest et al. (1991), performed with a fibre analyser, ANKOM 220. Determination of neutral detergent fibre (NDF) was on an ashfree basis, and included sodium dodecyl sulphate (Merc 822050). Determination of acid detergent fibre (ADF) included hexadecyl-trimethyl-ammonium bromide (Merc 102342), while acid detergent lignin (ADL) was established by hydrolysis of an ADF sample in $72 \%$ sulphuric acid. Hemicellulose (HCEL) was calculated as the difference between NDF and ADF, and cellulose (CEL) as the difference between ADF and ADL. The content of $\beta$-glucans was determined enzymatically according to the ICC standard method (1998) using a Megazyme kit, K-BGLU (Megazyme International Ireland Ltd., Wicklow, Ireland). All components were expressed on a dry matter basis.

The free fatty acid analysis was performed on a VARIAN CP3800 gas chromatograph. Separation was performed in a capillary column, namely CPWAX 52 CB $(60 \mathrm{~m} \times 0.25 \mathrm{~mm})$. The temperature of the injector and FID detector was $260{ }^{\circ} \mathrm{C}$. The column temperature was $120^{\circ} \mathrm{C}$ with a gradual increase to $210^{\circ} \mathrm{C}$. Helium was used as a carrier gas at a flow rate of $1.4 \mathrm{~cm}^{3} / \mathrm{min}$.

Amino acids were determined using an AAA 400 automatic amino acid analyser (INGOS, Czech Republic). Samples were subjected to acid hydrolysis in the presence of $6 \mathrm{M} \mathrm{HCl}$ at $105{ }^{\circ} \mathrm{C}$ for 24 hours. Sulphur-containing amino acids were ascertained separately in $6 \mathrm{M} \mathrm{HCl}$ after oxidative hydrolysis using a mixture of formic acid and hydrogen peroxide at a ratio $9: 1 \mathrm{v} / \mathrm{v}$, for $20 \mathrm{~h}$ at $4{ }^{\circ} \mathrm{C}$. Tryptophan was determined according to the method described in AOAC (2006). The amino acid composition was expressed in g/16 $\mathrm{g} \mathrm{N}$. Based on the amino acid composition in the protein of the oat grains, the following aspects were calculated: amino acids score (AAS) and essential amino acids index (EAAI) compared with egg white, used as the reference pattern (FAONHO/UNU, 1985). EAAI was calculated according to Oser (1951) as the geometric mean of the ratios of the essential amino acids in a protein to those of whole egg protein-reference pattern.

All the measurements were made in triplicate. Results were expressed as mean values. The data were subjected to a one-way analysis of variance (ANOVA). The significance of differences between means of the various forms of oats ( $\bar{X}_{\mathrm{H}}-$ hulled oats, $\bar{X}_{\mathrm{Dh}}$ - dehulled oats and $\bar{X}_{\mathrm{N}}$ - naked oats) was determined by Duncan's multiple range test using statistical computational software (Statistica PL, version 8.0).

\section{Results and Discussion}

The chemical composition of dry matter of the oat grains is given in Table 1 . The average contents of dry matter, ash and nitrogen free extract in grain of hulled $\left(\bar{x}_{\mathrm{H}}\right)$, dehulled $\left(\bar{x}_{\mathrm{Dh}}\right)$ and naked oats $\left(\bar{X}_{\mathrm{N}}\right)$ were not significantly different from one another. The mean contents of crude protein and ether extract in the grain of hulled oats (104.9 and $58.45 \mathrm{~g} / \mathrm{kg} \mathrm{DM}$, respectively) were lower $(P \leq 0.01)$ than in the grain of dehulled (137.1 and $83.29 \mathrm{~g} / \mathrm{kg} \mathrm{DM}$, respectively) and naked oats (126.7 and $84.09 \mathrm{~g} / \mathrm{kg} \mathrm{DM}$, respectively). As expected, the crude fibre content in dehulled $(13.49 \mathrm{~g} / \mathrm{kg} \mathrm{DM})$ and naked oats $(30.35 \mathrm{~g} / \mathrm{kg} \mathrm{DM})$ was lower $(P$ $\leq 0.01)$ than in hulled oats $(104.80 \mathrm{~g} / \mathrm{kg} \mathrm{DM})$. Dehulled oat, compared with naked oat, contained $8.2 \%$ more crude protein $(P \leq 0.05)$, with 2.2 -fold less crude fibre $(P \leq 0.01)$. In this study, the mean crude protein values of hulled and naked oat were much lower than the values (143 and $159 \mathrm{~g} / \mathrm{kg} \mathrm{DM}$, respectively) reported by Brand et al. (2003). In contrast, Givens et al. (2004) reported crude protein values of $93 \mathrm{~g} / \mathrm{kg}$ DM for hulled oats and $120 \mathrm{~g} / \mathrm{kg}$ DM for naked oats. Compared with other cereals, oat is unique in its high fat content (Frey \& Holland, 1999). The results of the present study showed that the removal of hulls from oat grains significantly increased the fat content, which was confirmed by other authors (Brand et al., 2003; SykutDomańska et al., 2013). The oats Investigated differed considerably in crude fibre content, and for the dehulled and naked oat grains were comparable with wheat, maize and barley. Tamime et al. (1997) and 
Medel et al. (1999) reported the crude fibre content of wheat, maize and barley as 1.3 to $2.2 \%, 2.1$ to $2.4 \%$ and 2.4 to $5.6 \%$, respectively.

Table 1 Chemical composition of hulled, dehulled and naked oat grains ( $\mathrm{g} / \mathrm{kg}$ dry matter)

\begin{tabular}{|c|c|c|c|c|c|c|c|}
\hline Oats & Cultivar / line & Dry matter & Ash & $\begin{array}{l}\text { Crude } \\
\text { protein }\end{array}$ & $\begin{array}{l}\text { Ether } \\
\text { extract }\end{array}$ & $\begin{array}{c}\text { Crude } \\
\text { fibre }\end{array}$ & $\begin{array}{c}\text { Nitrogen-free } \\
\text { extract }\end{array}$ \\
\hline \multirow{7}{*}{ Hulled oat } & Krezus & 894.5 & 21.0 & 106.1 & 52.8 & 109.7 & 710.5 \\
\hline & Bingo & 896.2 & 20.5 & 99.4 & 57.7 & 97.1 & 725.2 \\
\hline & STH 6106 & 913.0 & 22.7 & 105.0 & 63.0 & 110.7 & 698.6 \\
\hline & STH 6108 & 914.3 & 22.3 & 109.2 & 56.9 & 114.5 & 697.2 \\
\hline & STH 7105 & 894.4 & 19.2 & 104.7 & 62.0 & 92.0 & 722.1 \\
\hline & $\bar{X}_{\mathrm{H}}$ & $902.5^{a}$ & $21.13^{a}$ & $104.9^{A}$ & $58.45^{A}$ & $104.8^{A}$ & $710.7^{a}$ \\
\hline & SEM & 4.58 & 0.63 & 1.59 & 1.85 & 4.34 & 5.78 \\
\hline \multirow{7}{*}{$\begin{array}{l}\text { Dehulled } \\
\text { oat }\end{array}$} & Krezus & 893.7 & 20.8 & 139.1 & 75.7 & 15.3 & 749.2 \\
\hline & Bingo & 888.2 & 20.1 & 129.7 & 75.9 & 18.8 & 755.6 \\
\hline & STH 6106 & 906.8 & 18.7 & 130.2 & 90.9 & 12.7 & 744.6 \\
\hline & STH 6108 & 907.1 & 19.9 & 148.0 & 93.0 & 10.4 & 728.8 \\
\hline & STH 7105 & 896.1 & 19.5 & 138.6 & 81.1 & 10.4 & 750.5 \\
\hline & $\bar{X}_{\mathrm{Dh}}$ & $898.4^{a}$ & $19.78^{a}$ & $137.1^{\mathrm{Ba}}$ & $83.29^{B}$ & $13.49^{B}$ & $745.7^{a}$ \\
\hline & SEM & 3.73 & 0.35 & 3.37 & 3.67 & 1.59 & 4.58 \\
\hline \multirow{6}{*}{ Naked oat } & Polar & 891.5 & 19.9 & 136.5 & 90.0 & 22.8 & 730.8 \\
\hline & STH 7202 & 894.2 & 17.7 & 129.8 & 85.5 & 27.2 & 739.8 \\
\hline & STH 7205 & 896.3 & 17.3 & 119.5 & 81.8 & 36.4 & 745.0 \\
\hline & STH 7206 & 891.5 & 18.0 & 121.2 & 79.1 & 35.1 & 746.7 \\
\hline & $\bar{x}_{\mathrm{N}}$ & $893.4^{a}$ & $18.21^{a}$ & $126.7^{\mathrm{Bb}}$ & $84.09^{B}$ & $30.35^{C}$ & $740.6^{a}$ \\
\hline & SEM & 1.16 & 0.58 & 3.96 & 2.37 & 3.24 & 3.57 \\
\hline
\end{tabular}

$\bar{A}_{, \mathrm{B}, \mathrm{C}}$ Means $\bar{X}_{\mathrm{H}}, \bar{X}_{\mathrm{Dh}}$ and $\bar{X}_{\mathrm{N}}$ in columns with different superscripts differ significantly at $P \leq 0.01$.

${ }^{\mathrm{a}, \mathrm{b}}$ Means $\bar{X}_{\mathrm{H}}, \bar{X}_{\mathrm{Dh}}$ and $\bar{X}_{\mathrm{N}}$ in columns with different superscripts differ significantly at $P \leq 0.05$.

SEM: standard error of mean.

Reducing the proportion of hulls in grain oats decreased the concentration of the dietary fibre significantly (Table 2). Dehulled and naked oats contained less NDF (3.3- and 2.7-fold, respectively, $P$ $\leq 0.01$ ), ADF (7.7- and 3.4-fold, respectively, $P \leq 0.01$ ), ADL (3.5- and 2.2-fold, respectively, $P \leq 0.01$ ), HCEL (2.1- and 2.3-fold, respectively, $P \leq 0.01)$ and CEL (10.6 and 3.8-fold, respectively, $P \leq 0.01)$ than hulled oat. Dehulled oats, compared with naked oats contained higher concentrations of ADF $(P \leq 0.01), A D L(P \leq 0.01)$, CEL $(P \leq 0.01)$ and NDF $(P \leq 0.05)$. The concentrations of NDF, ADF and HCEL in hulled and naked oats in our study are broadly in line with results reported by Givens et al. (2004).

Oats contains $26 \%$ hull (Todorov, 1988), which is one of the main reasons for the higher fibre content. The oat hull contains $386 \mathrm{~g} \mathrm{ADF} / \mathrm{kg}$ and $718 \mathrm{~g} \mathrm{NDF} / \mathrm{kg}$ (Van der Merwe \& Smith, 1991). This demonstrates that the lower crude fibre content and favourable composition of dietary fibre in grains of dehulled oats than naked oats are mainly the result of lower proportions of hulls on the dehulled oat grains. The hull has a lower digestibility relative to the groat, and because of this, the proportion of hull in oats largely determines the energy value of the grain (Givens et al., 2004). Dehulling oat grains increases the nutritive value and concentration of metabolizable energy $(9 \%-10 \%)$ for poultry and pigs, which results mainly from a marked reduction in fibre content in dehulled grains (Peltonen-Sainio et al., 2004). A much higher content of digestible energy for pigs in the naked oats than in the hulled oats was reported by Brand et al. (2003) and Givens et al. (2004).

The average content of $\beta$-glucans in the tested hulled oat grain $(31.24 \mathrm{~g} / \mathrm{kg} \mathrm{DM})$ was lower $(P \leq 0.01)$ than in the grain of naked (by $41.4 \%$ ) and dehulled oats (by 52.5\%) (Table 2). The husk contains negligible amounts of $\beta$-glucans compared with the endosperm of the grain; thus naked oats contains a higher 
percentage of $\beta$-glucans (range, 3.6\% - 4.7\%) compared with hulled oats (range, $2.9 \%-3.5 \%$ ) (Zute et al., 2011). $\beta$-glucans decreases serum cholesterol, glucose and insulin levels in humans (Welch, 1995; Wood, 2007). However, for animal feed low $\beta$-glucans concentration is desirable, particularly for monogastric animals. Increased levels of $\beta$-glucans lead to decreased nutrient digestion and absorption in poultry (Burrows et al., 1992) and, to an extent, in pigs (Van Barneveld \& Hughes, 1994). $\beta$-glucans increase the viscosity of the digesta, leading to changes in the physiology and ecosystem of the gut (Choct et al., 1996).

Table 2 Components of dietary fibre of tested oat grains ( $\mathrm{g} / \mathrm{kg}$ dry matter)

\begin{tabular}{|c|c|c|c|c|c|c|c|}
\hline Oats & Cultivar / line & NDF & ADF & ADL & HCEL & CEL & ß-glucans \\
\hline \multirow{7}{*}{ Hulled oat } & Krezus & 380.3 & 183.7 & 33.65 & 196.6 & 150.1 & 27.5 \\
\hline & Bingo & 329.5 & 156.2 & 36.10 & 173.3 & 120.1 & 34.7 \\
\hline & STH 6106 & 314.6 & 156.5 & 27.25 & 158.2 & 129.2 & 32.0 \\
\hline & STH 6108 & 306.9 & 141.3 & 27.80 & 165.6 & 113.5 & 33.2 \\
\hline & STH 7105 & 297.2 & 154.1 & 26.30 & 143.1 & 127.8 & 28.9 \\
\hline & $\bar{x}_{\mathrm{H}}$ & $325.7^{A}$ & $158.4^{\mathrm{A}}$ & $30.22^{A}$ & $167.4^{A}$ & $128.1^{A}$ & $31.24^{A}$ \\
\hline & SEM & 14.64 & 6.93 & 1.95 & 8.85 & 6.17 & 1.34 \\
\hline \multirow{7}{*}{$\begin{array}{l}\text { Dehulled } \\
\text { oat }\end{array}$} & Krezus & 114.9 & 25.5 & 10.10 & 89.5 & 15.4 & 43.9 \\
\hline & Bingo & 81.5 & 18.7 & 8.25 & 66.8 & 10.5 & 48.8 \\
\hline & STH 6106 & 112.1 & 21.9 & 8.85 & 90.2 & 13.0 & 49.7 \\
\hline & STH 6108 & 88.4 & 17.0 & 7.70 & 71.4 & 9.5 & 50.6 \\
\hline & STH 7105 & 92.7 & 19.9 & 7.95 & 72.8 & 12.0 & 45.3 \\
\hline & $\bar{X}_{\mathrm{Dh}}$ & $97.9^{\mathrm{Ba}}$ & $20.6^{B}$ & $8.57^{B}$ & $78.12^{B}$ & $12.04^{B}$ & $47.64^{B}$ \\
\hline & SEM & 6.63 & 1.45 & 0.43 & 4.89 & 1.03 & 1.29 \\
\hline \multirow{6}{*}{ Naked oat } & Polar & 144.6 & 47.8 & 12.00 & 96.8 & 35.8 & 42.4 \\
\hline & STH 7202 & 108.8 & 51.2 & 13.80 & 57.7 & 37.4 & 46.3 \\
\hline & STH 7205 & 111.8 & 45.3 & 13.45 & 66.6 & 31.8 & 39.2 \\
\hline & STH 7206 & 110.9 & 43.7 & 14.75 & 67.2 & 29.0 & 48.9 \\
\hline & $\bar{x}_{\mathrm{N}}$ & $119.0^{\mathrm{Bb}}$ & $47.0^{\mathrm{C}}$ & $13.50^{\mathrm{C}}$ & $72.05^{B}$ & $33.48^{C}$ & $44.18^{B}$ \\
\hline & SEM & 8.55 & 1.63 & 0.57 & 8.53 & 1.91 & 2.12 \\
\hline
\end{tabular}

\footnotetext{
${ }_{\mathrm{A}, \mathrm{B}, \mathrm{C}}$ Means $\bar{X}_{\mathrm{H}}, \bar{X}_{\mathrm{Dh}}$ and $\bar{X}_{\mathrm{N}}$ in columns with different superscripts differ significantly at $P \leq 0.01$.

${ }^{\mathrm{a}, \mathrm{b}}$ Means $\bar{X}_{\mathrm{H}}, \bar{X}_{\mathrm{Dh}}$ and $\bar{X}_{\mathrm{N}}$ in columns with different superscripts differ significantly at $P \leq 0.05$.

NDF: neutral detergent fibre; ADF: acid detergent fibre; ADL: acid detergent lignin; HCEL: hemicellulose; CEL: cellulose. SEM: standard error of mean.
}

Compared with the hulled oats, dehulled and naked oat fat contained less saturated fatty acids (SFAs) $(P \leq 0.05)$, including C16:0 $(P \leq 0.05)$ and C14:0 $(P \leq 0.05)$ (Table 3$)$. The fat in the dehulled and naked oats contained about $79 \%$ unsaturated fatty acids (UFAs), compared to $74 \%$ in the hulled oats. One of the main UFAs was oleic acid, which is highly positively correlated with total fat content (Zhou et al., 1998). Lipids in the naked and dehulled oats contained more $(P \leq 0.05)$ oleic acid than in the hulled oat. Zhou et al. (1998) reported that, compared with other cereals, naked oat has considerably more UFAs. Oats are rich in polyunsaturated fatty acids (PUFAs), including essential fatty acids in mammalian nutrition, such as linoleic acid (C18: $2 n-6)$ and linolenic acid (C18: $3 n-3)$. The dehulled and naked oat fat contained more PUFAs ( $P$ $\leq 0.05)$, including C18:2 and C18:3 $(P \leq 0.05)$ compared with the hulled oat. Givens et al. (2004) reported a linoleic acid content in naked and hulled oats of $37.4 \%$ to $38.9 \%$ and a total fatty acid content of $36.2 \%$ to $37.1 \%$, respectively. The differences in the proportion of fatty acids (expressed as $\mathrm{g} / \mathrm{kg}$ oat), between the hull-less and hulled oats will be much larger owing to the significantly higher $(P \leq 0.01$; Table 1$)$ crude fat content in the dehulled and naked oats compared with hulled oats. UFAs of oat are regarded as nutritionally important owing to the high content of essential fatty acids (Youngs, 1986). 
Table 3 Fatty acid composition of the tested oat grains (\% of total fatty acids)

\begin{tabular}{|c|c|c|c|c|c|c|c|c|c|c|c|c|c|c|c|}
\hline Oats & Cultivar / line & C14:0 & C16:0 & C18:0 & C20:0 & C16:1 & C18:1 & C20:1 & C22:1 & C18:2 & C18:3 & SFA & UFA & MUFA & PUFA \\
\hline \multirow{7}{*}{ Hulled oat } & Krezus & 0.39 & 21.13 & 1.87 & 0.14 & 0.20 & 41.63 & 0.99 & 0.25 & 30.54 & 0.52 & 23.53 & 74.1 & 43.1 & 31.1 \\
\hline & Bingo & 0.29 & 20.63 & 2.57 & 0.19 & 0.18 & 42.71 & 1.00 & 0.37 & 29.32 & 0.50 & 23.68 & 74.1 & 44.3 & 29.8 \\
\hline & STH 6106 & 0.36 & 20.57 & 2.39 & 0.21 & 0.31 & 44.06 & 0.99 & 0.53 & 27.67 & 0.73 & 23.53 & 74.3 & 45.9 & 28.4 \\
\hline & STH 6108 & 0.34 & 21.25 & 2.03 & 0.15 & 0.19 & 43.61 & 0.96 & 0.62 & 27.81 & 0.86 & 23.77 & 74.1 & 45.4 & 28.7 \\
\hline & STH 7105 & 0.39 & 21.39 & 1.86 & 0.16 & 0.18 & 43.31 & 1.00 & 0.53 & 28.30 & 0.94 & 23.80 & 74.3 & 45.0 & 29.2 \\
\hline & $\bar{X}_{H}$ & $0.35^{a}$ & $20.99^{a}$ & 2.14 & 0.17 & $0.21^{a}$ & 43.06 & $0.99^{a}$ & 0.46 & $28.73^{\mathrm{a}}$ & $0.71^{a}$ & $23.66^{a}$ & 74.16 & 44.72 & $29.44^{\mathrm{a}}$ \\
\hline & SEM & 0.02 & 0.17 & 0.14 & 0.01 & 0.03 & 0.42 & 0.01 & 0.07 & 0.54 & 0.09 & 0.06 & 0.05 & 0.49 & 0.47 \\
\hline \multirow{7}{*}{$\begin{array}{l}\text { Dehulled } \\
\text { oat }\end{array}$} & Krezus & 0.24 & 19.51 & 2.02 & 0.16 & 0.17 & 42.94 & 0.82 & 0.27 & 32.20 & 0.91 & 21.93 & 77.3 & 44.2 & 33.1 \\
\hline & Bingo & 0.23 & 18.67 & 1.92 & 0.17 & 0.16 & 43.01 & 1.12 & 0.36 & 32.94 & 0.64 & 20.99 & 78.2 & 44.7 & 33.6 \\
\hline & STH 6106 & 0.30 & 18.01 & 2.03 & 0.22 & 0.26 & 43.63 & 1.01 & 0.59 & 32.52 & 0.86 & 20.56 & 78.9 & 45.5 & 33.4 \\
\hline & STH 6108 & 0.31 & 17.78 & 1.68 & 0.14 & 0.20 & 42.84 & 0.98 & 0.63 & 33.62 & 0.96 & 19.91 & 79.3 & 44.7 & 34.6 \\
\hline & STH 7105 & 0.26 & 19.06 & 1.75 & 0.15 & 0.16 & 43.01 & 0.99 & 0.53 & 32.54 & 0.99 & 21.22 & 78.3 & 44.7 & 33.5 \\
\hline & $\bar{x}_{\mathrm{Dh}}$ & $0.27^{\mathrm{b}}$ & $18.61^{b}$ & 1.88 & 0.17 & $0.19^{b}$ & 43.09 & $0.98^{\mathrm{a}}$ & 0.48 & $32.76^{b}$ & $0.87^{b}$ & $20.92^{\mathrm{b}}$ & 78.39 & 44.75 & $33.63^{b}$ \\
\hline & SEM & 0.02 & 0.32 & 0.07 & 0.01 & 0.02 & 0.14 & 0.05 & 0.09 & 0.24 & 0.06 & 0.34 & 0.34 & 0.23 & 0.25 \\
\hline \multirow{6}{*}{ Naked oat } & Polar & 0.20 & 17.57 & 1.74 & 0.16 & 0.14 & 44.34 & 0.77 & 0.27 & 33.21 & 0.95 & 19.71 & 79.5 & 45.4 & 34.2 \\
\hline & STH 7202 & 0.23 & 15.94 & 1.85 & 0.17 & 0.23 & 43.92 & 0.85 & 0.47 & 34.11 & 0.75 & 18.15 & 80.3 & 45.5 & 34.9 \\
\hline & STH 7205 & 0.25 & 17.51 & 2.09 & 0.10 & 0.18 & 41.31 & 0.70 & 0.40 & 35.04 & 0.90 & 19.75 & 78.5 & 42.6 & 35.9 \\
\hline & STH 7206 & 0.23 & 16.77 & 1.87 & 0.15 & 0.18 & 42.35 & 0.82 & 0.48 & 34.90 & 1.01 & 18.83 & 79.8 & 43.9 & 35.9 \\
\hline & $\bar{X}_{\mathrm{N}}$ & $0.23^{b}$ & $17.00^{b}$ & 1.89 & 0.15 & $0.18^{b}$ & 42.98 & $0.78^{b}$ & 0.41 & $34.32^{b}$ & $0.90^{b}$ & $19.09^{b}$ & 79.55 & 44.33 & $35.21^{b}$ \\
\hline & SEM & 0.01 & 0.29 & 0.05 & 0.02 & 0.01 & 0.75 & 0.03 & 0.04 & 0.42 & 0.06 & 0.33 & 0.36 & 0.74 & 0.45 \\
\hline
\end{tabular}

\footnotetext{
${ }^{\mathrm{a}, \mathrm{b}}$ Means $\bar{X}_{\mathrm{H}}, \bar{X}_{\mathrm{Dh}}$ and $\bar{X}_{\mathrm{N}}$ in columns with different superscripts differ significantly at $P \leq 0.05$.

SEM: standard error of mean.

SFA: saturated fatty acids; UFA: unsaturated fatty acids; MUFA: monounsaturated fatty acids; PUFA: polyunsaturated fatty acids.
} 
Table 4 Essential amino acid composition of protein of the tested oat grains $(\mathrm{g} / 16 \mathrm{~g} \mathrm{~N})$

\begin{tabular}{|c|c|c|c|c|c|c|c|c|c|c|c|c|}
\hline Item & Cultivar / line & Lys & Met & Met+Cys & Thr & Ile & Trp & Val & Leu & His & Phe & Phe+Tyr \\
\hline \multirow{7}{*}{ Hulled oat } & Krezus & 3.37 & 1.77 & 4.44 & 2.68 & 2.73 & 1.52 & 4.64 & 6.43 & 2.54 & 4.23 & 6.14 \\
\hline & Bingo & 3.45 & 1.62 & 4.26 & 2.91 & 2.91 & 1. 47 & 4.57 & 6.74 & 2.70 & 4.28 & 6.25 \\
\hline & STH 6106 & 3.02 & 1.51 & 4.23 & 2.92 & 2.66 & 1.35 & 4.13 & 5.95 & 1.63 & 4.08 & 5.64 \\
\hline & STH 6108 & 3.21 & 1.65 & 4.54 & 2.98 & 2.73 & 1.14 & 4.33 & 6.68 & 1.83 & 3.99 & 5.37 \\
\hline & STH 7105 & 3.71 & 1.82 & 4.53 & 3.02 & 3.11 & 1.20 & 5.12 & 7.21 & 2.60 & 4.65 & 6.85 \\
\hline & $\bar{X}_{\mathrm{H}}$ & $3.35^{\mathrm{a}}$ & 1.67 & 4.40 & $2.90^{\mathrm{a}}$ & $2.83^{a}$ & 1.32 & 4.56 & 6.60 & 2.26 & 4.25 & 6.09 \\
\hline & SEM & 0.12 & 0.05 & 0.07 & 0.06 & 0.08 & 0.11 & 0.17 & 0.21 & 0.22 & 0.11 & 0.31 \\
\hline \multirow{7}{*}{$\begin{array}{l}\text { Dehulled } \\
\text { oat }\end{array}$} & Krezus & 3.35 & 1.73 & 4.45 & 2.92 & 3.08 & 1.22 & 4.24 & 6.24 & 2.87 & 4.38 & 6.31 \\
\hline & Bingo & 3.29 & 1.76 & 4.44 & 2.69 & 3.16 & 1.08 & 4.20 & 6.36 & 3.06 & 4.09 & 5.98 \\
\hline & STH 6106 & 3.55 & 1.69 & 4.48 & 3.05 & 2.77 & 1.22 & 4.46 & 6.51 & 1.83 & 4.41 & 5.65 \\
\hline & STH 6108 & 3.50 & 1.62 & 4.19 & 2.94 & 2.76 & 1.14 & 4.25 & 6.24 & 1.83 & 4.37 & 6.18 \\
\hline & STH 7105 & 3.39 & 1.98 & 4.86 & 2.84 & 3.20 & 1.27 & 4.82 & 6.53 & 2.08 & 4.54 & 6.96 \\
\hline & $\bar{X}_{\mathrm{Dh}}$ & $3.42^{\mathrm{a}}$ & 1.76 & 4.48 & $2.89^{a}$ & $2.99^{a}$ & 1.19 & 4.39 & 6.38 & 2.33 & 4.36 & 6.23 \\
\hline & SEM & 0.05 & 0.06 & 0.11 & 0.06 & 0.10 & 0.03 & 0.12 & 0.06 & 0.26 & 0.07 & 0.20 \\
\hline \multirow{6}{*}{ Naked oat } & Polar & 3.52 & 1.67 & 4.20 & 2.99 & 3.19 & 1.15 & 4.73 & 6.71 & 3.09 & 4.46 & 6.11 \\
\hline & STH 7202 & 3.66 & 1.83 & 4.60 & 3.02 & 3.19 & 1.26 & 4.71 & 6.54 & 2.13 & 4.69 & 7.44 \\
\hline & STH 7205 & 4.10 & 1.89 & 4.69 & 3.70 & 3.73 & 1.21 & 4.92 & 7.54 & 3.09 & 5.06 & 7.20 \\
\hline & STH 7206 & 3.84 & 1.79 & 4.61 & 3.80 & 3.51 & 1.12 & 4.85 & 7.79 & 2.94 & 5.11 & 7. 04 \\
\hline & $\bar{X}_{\mathrm{N}}$ & $3.78^{b}$ & 1.80 & 4.53 & $3.38^{b}$ & $3.41^{b}$ & 1.19 & 4.80 & 7.15 & 2.81 & 4.83 & 6.90 \\
\hline & SEM & 0.12 & 0.05 & 0.11 & 0.22 & 0.13 & 0.03 & 0.05 & 0.31 & 0.23 & 0.15 & 0.37 \\
\hline
\end{tabular}

${ }^{\text {a, b }}$ Means $\bar{X}_{\mathrm{H}}, \bar{X}_{\mathrm{Dh}}$ and $\bar{X}_{\mathrm{N}}$ in columns with different superscripts differ significantly at $P \leq 0.05$.

SEM: standard error of mean. 
Protein in naked oat grains contained more ( $P \leq 0.05)$ lysine (Lys), threonine (Thr) and isoleucine (Ile) than in the dehulled and hulled oats (Table 4). The levels of the remaining amino acids in all oat grain $(\mathrm{g} / 16 \mathrm{~g}$ $\mathrm{N}$ ) are similar, but if expressed as $\mathrm{g} / \mathrm{kg}$ of oat, there will be significant differences between the hull-less and the hulled oats, owing to the significantly higher crude protein content in the dehulled and naked oats than in the hulled oats. The content of sulphur-containing amino acids in the protein of the analysed oat lines was high, in the range of $4.40-4.53 \mathrm{~g} / 16 \mathrm{~g} \mathrm{~N}$, which makes oats a good complementary protein source to legumes (Pedó et al., 1999). The content of essential amino acids in protein of naked and dehulled oats was comparable with the level in naked oats reported by Zarkadas et al. (1995) and dehulled oats reported by Pedo et al. (1999).

Total content of essential amino acids (EAAs) in the protein of naked oats was $12 \%$ higher $(P \leq 0.05)$ than in dehulled and hulled oats (Table 5). The content of EAAs was reflected in the essential amino acid index (EAAI) values, which in relation to the reference pattern (egg white) in naked oats (73.19) was higher $(P \leq 0.05)$ than in dehulled (67.12) and hulled oats (67.90). Comparisons with the reference pattern (egg white) revealed that lysine was the most limited amino acid in all analysed oat grains in the range: $54.0 \%$ (naked oat), $48.8 \%$ (dehulled oat) and $48.1 \%$ (hulled oat) of the reference pattern. The amino acids score (AAS) value for naked oats was higher $(P \leq 0.05)$ than that for dehulled and hulled oats. Other authors found that lysine is the most limited amino acid in naked and dehulled oat grains (Zarkadas et al., 1995; Pedó et al., 1999).

Table 5 Coefficients of nutritive value of tested oat grain protein

\begin{tabular}{|c|c|c|c|c|}
\hline Item & Cultivar / line & EAAs (g/16 g N) & EAAI & AAS $_{\text {Lys }}(\%)$ \\
\hline \multirow{7}{*}{ Hulled oat } & Krezus & 34.7 & 69.4 & 48.2 \\
\hline & Bingo & 35.1 & 70.0 & 49.2 \\
\hline & STH 6106 & 31.3 & 62.6 & 43.2 \\
\hline & STH 6108 & 32.5 & 64.2 & 46.8 \\
\hline & STH 7105 & 37.4 & 73.3 & 52.9 \\
\hline & $\bar{X}_{\mathrm{H}}$ & $34.21^{\mathrm{a}}$ & $67.90^{\mathrm{a}}$ & $48.12^{\mathrm{a}}$ \\
\hline & SEM & 1.06 & 2.07 & 1.39 \\
\hline \multirow{7}{*}{$\begin{array}{l}\text { Dehulled } \\
\text { oat }\end{array}$} & Krezus & 34.5 & 68.5 & 48.0 \\
\hline & Bingo & 34.2 & 65.8 & 46.9 \\
\hline & STH 6106 & 33.3 & 65.9 & 50.7 \\
\hline & STH 6108 & 33.1 & 64.8 & 50.0 \\
\hline & STH 7105 & 35.7 & 70.2 & 48.1 \\
\hline & $\bar{X}_{\mathrm{Dh}}$ & $34.13^{\mathrm{a}}$ & $67.12^{a}$ & $48.82^{a}$ \\
\hline & SEM & 0.46 & 0.89 & 0.59 \\
\hline \multirow{6}{*}{ Naked oat } & Polar & 35.7 & 68.8 & 50.3 \\
\hline & STH 7202 & 37.0 & 72.0 & 52.3 \\
\hline & STH 7205 & 40.4 & 76.4 & 58.6 \\
\hline & STH 7206 & 39.7 & 75.5 & 54.9 \\
\hline & $\bar{X}_{N}$ & $38.18^{b}$ & $73.19^{b}$ & $54.03^{b}$ \\
\hline & SEM & 1.11 & 2.13 & 1.24 \\
\hline
\end{tabular}

${ }^{\mathrm{a}, \mathrm{b}}$ Means $\bar{X}_{\mathrm{H}}, \bar{X}_{\mathrm{Dh}}$ and $\bar{X}_{\mathrm{N}}$ in columns with different superscripts differ significantly at $P \leq 0.05$. EAA: essential amino acids; EAAl: essential amino acid index; AAS $_{\text {Lys: }}$ : Amino acids score (Lys). SEM: standard error of mean.

The amino acid composition and biological value of oat protein are better than that of other cereals such as wheat, barley or maize (McMullen, 2000). In these cereals, the biological value of the protein declines markedly in the grain with increasing crude protein content. The major storage proteins of oats are 
globulins, which have a higher concentration of lysine and other essential amino acids than prolamins, which are typical cereal storage proteins (Shewry \& Halford, 2002).

Owing to its composition, especially low fibre content, naked and dehulled oat can be a valuable component of diet for monogastric animals. Naked oat can be a substitute for maize and wheat in growerfinisher pig diets (Brand \& Van der Merwe, 1996; Flis et al., 2005).

\section{Conclusion}

The results of this study indicated that reducing the proportion of hulls in oat grains resulted in a significant decrease in dietary fibre content and a significant increase in nutrient content. Such changes can be achieved by the cultivation of naked oats or separation by dehulling grain prior to feeding to animals.

\section{References}

AOAC, 2006. Official Methods of Analysis (18 $8^{\text {th }}$ ed.). Association of Official Analytical Chemists. Washington, D.C., USA.

Biel, W., Bobko, K. \& Maciorowski, R., 2009. Chemical composition and nutritive value of husked and naked oats grain. J. Cereal Sci. 49, 413-418.

Brand, T.S. \& Van der Merwe, J.P., 1996. Naked oats (Avena nuda) as substitute for maize in the diets of weanling and grower-finisher pigs. Anim. Feed. Sci. Technol. 57, 139-147.

Brand, T.S., Cruywagen, C.W., Brandt, D.A., Viljoen, M. \& Burger, W.W., 2003. Variation in the chemical composition, physical characteristics and energy values of cereal grains produced in the Western Cape area of South Africa. S. Afr. J. Anim. Sci. 33, 117-126.

Burrows, V.D., Cave, N.A. \& Hamilton, R.M.G., 1992. Breeding naked oat for food, feed and industrial purposes in Canada. In: Proceedings of $4^{\text {th }}$ International Oat Conference, Adelaide, Australia, 64-68.

Chen, J., He, J., Wildman, R.P., Reynolds, K. \& Streiffer, W., 2006. A randomized controlled trial of dietary fiber intake on serum lipids. Eur. J. Clin. Nutr. 60, 62-68.

Choct, M., Hughes, R.J., Wang, J., Bedford, M.R., Morgan, A.J. \& Annison, G., 1996. Increased small intestinal fermentation is partly responsible for the anti-nutritive activity of non-starch polysaccharides in chickens. Br. Poult. Sci. 37, 609-621.

FAO/WHO/UNU, 1985. Energy and Protein Requirements Report of a Joint Expert Consultation. WHO Technical Report Series, no 724. Geneva, WHO.

Flis, M., Maślanek, A. \& Antoszkiewicz, Z., 2005. Growth performance, nutrient digestibility and protein utilization in growing pigs fed naked oat with $\beta$-glucanase supplementation as a substitute for wheat. Wet. Zoot. 31, 49-52.

Frey, K.J. \& Holland, J.B., 1999. Nine cycles of recurrent selection for increased groat-oil content in oat. Crop Sci. 39, 1636-1641.

Givens, D.I., Davies, T.W. \& Laverick, R.M., 2004. Effect of variety, nitrogen fertiliser and various agronomic factors on the nutritive value of husked and naked oats grain. Anim. Feed Sci. Technol. 113, 169-181.

Guenter, W., 1993. Impact of feed enzymes on nutrient utilization of ingredients in growing poultry. J. Appl. Poult. Res. 2, 82-84.

Hsueh, C.W., Chia, H.H., Jeng, D.H., Mon, Y.Y., Shing, J.W. \& Chau, J.W., 2011. Inhibitory effect of whole oat on aberrant crypt foci formation and colon tumor growth in ICR and BALB/c mice. J. Cereal Sci. $53,73-77$.

ICC, 1998. International Association for Cereal Science and Technology (ICC) standard method no. 166. Determination of ß-glucan in barley, oat and rye. ICC Secretariat, Vienna.

Klose, C. \& Arendt, E.K., 2012. Proteins in oats; their synthesis and changes during germination: A review. Crit. Rev. Food Sci. Nutr. 52, 629-639.

Koehler, P. \& Wieser, H., 2013. Chemistry of cereal grains. In: Handbook on Sourdough Biotechnology. Eds: Gobbetti, M. \& Gänzle, M., Springer Science+Business Media, New York. pp. 11-45.

McMullen, M.S., 2000. Oats. In: Handbook of Cereal Science and Technology. Eds: Kulp, C. \& Ponte, J.G., 270 Madison Avenue, New York. pp. 127-148.

Medel, P., Salado, S., de Blas, J.C. \& Mateos, G.G., 1999. Processed cereals in diets for early-weaned piglets. Anim. Feed Sci. Technol. 82, 145-156.

Morris, J.R., 1990. Oats: naked. In: Non-traditional Feed Sources for Use in Swine Production. Eds: Thacker, P.A. \& Kirkwood, R.N., Butterworth, London, UK. pp. 275-284.

Oser, B.L, 1951. Methods for the integrating essential amino acid content in the nutritional evaluation of protein. J. Am. Diet. Assoc. 27, 399-404.

Pedó, I., Sgarbieri, V.C. \& Gutkoski, L.C., 1999. Protein evaluation of four oat (Avena sativa L.) cultivars adapted for cultivation in the south of Brazil. Plant Foods Hum. Nutr. 53, 297-304. 
Peltonen-Sainio, P., Kontturi, M., Rajala, A. \& Kirkkari, A.M., 2004. Impact dehulling oat grain to improve quality of on-farm produced feed 1 . Hullability and associated changes in nutritive value and energy content. Agric. Food Sci. 13, 18-28.

Peterson, D.M., 1998. Malting oats: Effects on chemical composition of hulled and hull-less genotypes. Cereal Chem. 75, 230-234.

Shewry, P.R. \& Halford, N.G., 2002. Cereal seed storage proteins: structures, properties and role in grain utilization. J. Exp. Bot. 53, 947-958.

Sykut-Domańska, E., Rzedzicki, Z. \& Nita, Z., 2013. Chemical composition variability of naked and husked oat grain (Avena sativa L.). Cereal Res. Comm. 41, 327-337.

Tamime, A.Y., Muir, D.D., Barclay, M.N.I., Khaskheli, M. \& McNulty, D., 1997. Laboratory-made Kishk from wheat, oat and barley: 1. Production and comparison of chemical and nutritional composition of Burghol. Food Res. Int. 30, 311-317.

Todorov, N.A., 1988. Feeds and feedstuffs in Europe. 2.3 Cereals, pulses and oilseeds. Livest. Prod. Sci. 19, 47-95.

Van Barneveld, R.J. \& Hughes, R.J., 1994. The nutritive value of lupins for pigs and poultry. In: Proceedings of First Australian Lupin Technical Symposium, Perth, Western Australia, 49-57.

Van der Merwe, F.J. \& Smith, W.A., 1991. Dierevoeding. Anim. Sci. (Pty) Ltd., Pinelands, South Africa.

Van Soest, P.J., Robertson, J.B. \& Lewis, B.A., 1991. Methods for dietary fiber, neutral detergent fiber, and nonstarch polysaccharides in relation to animal nutrition. J. Dairy Sci. 74, 3583-3597.

Welch, R.W., 1995. Oats in human nutrition and health. In: The oat crop - Production and utilization. Ed: Welch, R.W., Chapman \& Hall, London. pp. 433-479.

Wood, P.J., 2007. Cereal ß-glucans in diet and health. J. Cereal Sci. 46, 230-238.

Youngs, V.L., 1986. Oat lipids and lipid-related enzymes. In: Oats: Chemistry and Technology. Ed: Webster, F.H., American Association of Cereal Chemist, Inc. Minnesota. pp. 205-226.

Zarkadas, C.G., Yu, Z. \& Burrows, V.D., 1995. Protein quality of three new Canadian developed naked oat cultivars using amino acid compositional data. J. Agric. Food Chem. 43, 415-421.

Zhou, M.X., Glennie Holmes, M., Robards, K. \& Helliwell, S., 1998. Fatty acid composition of lipids of Australian oats. J. Cereal Sci. 28, 311-319.

Zute, S., Berga, L. \& Vícupe, Z., 2011. Variability in endosperm $\beta$-glucan content of the husked and naked oat genotypes. Acta Biol. Univ. Daugavp. 11, 192-200. 